\title{
Study of Galectin 3 and Matrix Metalloproteinase-9 as Prognostic Markers in Colon Cancer
}

\author{
Mohamed Ahmed Badawy*, Iman Attia Abdelgawad *, \\ Asmaa Khamees Abdelgawad ** \\ Department of Clinical pathology*, NCI, Biochemistry**, \\ Faculty of Science - Cairo University, Egypt
}

\begin{abstract}
Objectives: The present study was carried out to evaluate the diagnostic role of galectin 3 and matrix metalloproteinase 9 in 50 consecutive newly diagnosed colon cancer patients, who presented to the Outpatient Clinic of the NCI over the period 2011-2012 and to compare their serum levels before treatment with those of 15 benign colon lesions patients, 15 normal controls subjects, and in 16 patients of the cancer colon group after treatment. Also, to compare these studied markers with CEA, CA 19.9 and some prognostic factors of cancer colon. Methods: Serum concentration of CEA and CA19.9 were evaluated using Axsym and MMP9 and Galectin 3 antigen were assessed using ELISA technique. Results: Serum levels of MMP9, CEA , and CA 19.9 showed highest results in the malignant group before treatment, followed by the patient group with benign lesion, then the malignant group after treatment and lastly comes the control group. While galectin 3 showed the highest results in the malignant group, followed by the benign then the control and lastly comes the after treatment group. Diagnostic performance of all the studied markers at the chosen cutoffs, CEA (21 ng/ml), CA19.9 (58 U /ml), MMP9 (90.9 $\mathrm{ng} / \mathrm{ml})$ and galectin $3(4.8 \mathrm{ng} / \mathrm{ml})$,galectin 3 showed the highest sensitivity, followed by CEA, and then CA19.9 and lastly MMP9 (96.9\%, 92.3\%, 81.5\% and $75.4 \%$ respectively). As regards specificity \% CEA, CA19.9 and MMP9 showed 100\% specificity each, while galectin 3 showed relatively lower specificity \% (90.3\%). Galectin 3 and CEA showed comparable high diagnostic accuracy (94.8\%) followed by CA19.9 (87.5\%) then MMP9 (83.3\%). On comparing diagnostic performance for the studied tumor markers in double combinations, the best sensitivity (98.5\%) was obtained when combining galectin 3 \& CA19.9 at cut offs $(4.8 \mathrm{ng} / \mathrm{ml}-58 \mathrm{U} / \mathrm{ml})$ respectively and galectin $3 \&$ \&MP9 at cutoffs $(4.8 \mathrm{ng} / \mathrm{ml}-90.9 \mathrm{ng} / \mathrm{m})$ respectively. As regards specificity, the double combination between CEA \& CA19.9 at cut offs (21 $\mathrm{ng} / \mathrm{ml}-58 \mathrm{U} / \mathrm{ml}))$ respectively and MMP9 \& CA19.9 at cut offs $(90.9 \mathrm{ng} / \mathrm{ml}-58 \mathrm{U}$ $/ \mathrm{ml}$ ) respectively showed the highest specificity of $100 \%$ each, on studying the correlation between all the studied tumor markers, there were significant positive correlations between CEA \& CA19.9, CEA \& Galectin 3, CEA \& MMP9, CA19.9 \& Galectin 3, CA19.9 \& MMP9 and MMP9 \& Galectin 3 ( $p=0.0001)$ each.
\end{abstract}

Keywords: Galectin 3, MMP9, Colon Cancer, tumor marker 


\section{INTRODUCTION}

Colorectal cancer is the third most common cancer and the second most common cause of cancer deaths in the United States where the vast majority of cases occurs over the age of 60 years ${ }^{(1)}$. In Egypt, the relative frequency of cancer colon at the National cancer Institute, Cairo University from 2002 to 2007 was (3$5 \%)^{(2)}$.

The endogenous, $\beta$-galactosidebinding protein galectin-3 is a member of a family of carbohydratebinding proteins that have been implicated in cell growth, differentiation, adhesion, malignant transformation and apoptosis ${ }^{(3)}$. It also, plays a role in the metastasis of several carcinomas ${ }^{(4)}$.

A study done by Iacovazzi et al., ${ }^{\text {(5) }}$ showed that galectin-3 levels were higher in sera of non metastatic colorectal cancer patients than in controls, particularly in more differentiated tumors.

Matrix metalloproteinase 9 or gelatinase $\mathrm{B}$ is a member of matrix metalloproteinases family which is structurally related to zinc-dependent endopeptidases proteolytic enzymes that are collectively capable of degrading essentially all components of extracellular matrix (ECM) including the basement membrane and type IV collagen. They are associated with tissue remodeling in normal and pathological processes characterized by excessive degradation of ECM ${ }^{(6)}$, as rheumatoid arthritis, osteoarthritis, periodontitis, autoimmune blistering disorders of the skin, they also play a role in the development, invasion and metastasis ${ }^{(7)}$ of malignant tumors as colorectal $^{(8)}$, gastric ${ }^{(9)}$, lung ${ }^{(10)}$, and breast cancer ${ }^{\text {(11) }}$.

Numerous studies have demonstrated increased MMP-2 and MMP-9 mRNA, protein, and/or activity in colorectal tumor specimens compared to normal colonic mucosa $^{.(12)}$. Several investigations have shown that increased gelatinase expression is associated with increased tumor aggressiveness.

Galectin-3, a 30-kDa chimera carbohydrate-binding protein is composed of three distinct structural motifs, an amino terminal domain consisting of 12 amino acid residues, preceding an amino terminal half of collagen-like sequence containing Pro-Gly-Tyr tandem repeats, and a sugar-binding carboxy terminal half ${ }^{(13)}$. The collagen-like domain of galectin-3 is susceptible to rapid and efficient cleavage by MMPs, in particular MMP-2, MMP-9, and membrane type $1-\mathrm{MMP}$ resulting in the generation of a $22 \mathrm{kDa}$ cleaved product ${ }^{(14)}$.

\section{AIM OF WORK}

To evaluate the role of galectin 3 and matrix metalloproteinase 9 in newly diagnosed colon cancer patients before treatment, and to compare their serum levels with the corresponding levels after treatment, with those of patient with benign colon lesion, and normal controls healthy subjects, Serum concentration of galectin 3 and matrix metalloproteinase 9 will also be compared with CEA, CA 19.9 and some prognostic factors of cancer colon. 


\section{PATIENTS \& METHODS}

This study was conducted on newly diagnosed cancer colon patients who presented to the Outpatient Clinic of the National Cancer Institute over a period of one year from 2011-2012. Patients were classified into

1- Colon cancer patients before treatment group: This group included 50 patients 24 males, 26 females evaluated before receiving any line of treatment. Their age ranged from 24 to $72,47 / 50(94 \%)$ were grade II, $3 / 50(6 \%)$ were grade III. As regards the stage, $33 / 50(66 \%)$ were stage II, $10 / 50$ $(20 \%)$ were stage III, and $7 / 50$ (14\%) were stage IV.

2- Colon cancer patients after treatment: This group included 16 patients: 10 males and 6 females who were evaluated after finishing their chemotherapy courses. Their ages ranged from 38 to $66,15 / 16$ $(93.75 \%)$ were grade II, and $1 / 16$ $(6.25 \%)$ was grade III. As regard the stage, $11 / 16(68.75 \%)$ were stage II, 4/16 (25\%) were stage III and $1 / 16(6.25 \%)$ was stage IV.

3- Benign colon lesion patients group: confirmed by biopsy and pathological examination: this group included 15 benign colon lesion 9 males and 6 females, their ages ranged from 45 to 78 .

4- Normal control group: This group included 15 normal apparently healthy volunteers; they were 5 males and 10 females, Their age ranged from 19 to 52 .

Serum samples were collected from both patients and controls and were subjected to the following: a- Tumor markers used for the diagnosis and prognosis of cancer colon: CEA and CA19.9 using AxSYM (3K4766 AxSYM CEA, 7A50-21 AxSYM CA19.9)

b- Serum concentration of MMP9 and Galectin 3 antigen using ELISA technique.( human galectin 3 ELISA BMS279/2, Human MMP-9 ELISA BMS2016/2).

\section{RESULTS}

Table (1) shows the patients characteristics of the cancer colon patients

Table (2) shows the patients characteristics of the after treatment cancer colon patients

As regards, the benign colon patients, seven out of fifteen patients (46.6\%) had tubular adenoma, 4/15 (26.6\%) had hyperplasia, 1/15 (6.6\%) had ulcerative colitis and 3/15 (20\%) had inflammation.

Comparing serum level of CEA, CA19.9, galectin3 and MMP9 between the 4 studied groups revealed statistically significant difference ( $\mathrm{p}$ value $<0.0001$ each).

Comparison the studied tumor markers between the different groups revealed statistically significant difference between each pair.

CEA was statistically significant for stage and lymph node metastasis and distant metastasis ( $\mathrm{p}$-value $0.0001, \quad 0.0001$ and 0.0026 respectively), CA19.9 was statistically significant for distant metastasis, stage and pathology (p-value <.0001, 0.0041 and 0.0043 respectively), galectin3 was statistically significant 
for distant metastasis (p-value 0.0044); MMP9 showed no significant result with any of the prognostic factors. No significant correlation could be detected between age and MMP9, CEA, CA19.9 and galectin3 (p -value 0.087, 0.137, 0.183 and 0.292 respectively).

The diagnostic accuracy of galectin 3 showed the highest sensitivity, followed by CEA, and then CA19.9 and lastly MMP9 (96.9\%, 92.3\%, 81.5\% and 75.4\% respectively). As regards specificity $\%$ CEA, CA19.9 and MMP9 showed $100 \%$ specificity each, while galectin 3 showed relatively lower specificity $\%(90.3 \%)$.

Double combination between galectin 3 and CEA showed comparable high diagnostic accuracy (94.8\%) followed by CA19.9 (87.5\%) then MMP9 (83.3\%). The best sensitivity $(98.5 \%)$ was obtained when combining galectin 3 \& CA19.9 and Galectin 3 \& MMP9. Double combination between CEA \& CA19.9 and MMP9 \& CA19.9 showed the highest specificity of $100 \%$ each, followed by CEA \& MMP9 with specificity of $91.9 \%$. Highest diagnostic accuracy \% was obtained by combing CEA \& CA19.9 (85.9\%) followed by CEA \& MMP9 (84.9\%)

There were significant positive correlations between CEA \& CA19.9, CEA \& Galectin 3, CEA \& MMP9, CA19.9 \& Galectin 3, CA19.9 \& MMP9 and MMP9 \& Galectin 3 $(\mathrm{p}=0.0001)$.

Table (1): Patients characteristics of the cancer colon group

\begin{tabular}{|l|l|l|}
\hline & \multicolumn{1}{|c|}{ (\%) } \\
\hline Sex & Male & $24(48)$ \\
& Female & $26(52)$ \\
\hline Prognostic factors & Stage & \\
& II & $33(66)$ \\
& IIII & $7(20)$ \\
& IV & $74)$ \\
\hline & Grade & $47(94)$ \\
& II & $3(6)$ \\
& III & $37(74)$ \\
& Pathology & $13(26)$ \\
\hline & Adenocarcinoma & $13(26)$ \\
& Other pathological types & $37(74)$ \\
\hline & Tumor site & $11(22)$ \\
\hline
\end{tabular}

Other pathological types $=2(4 \%)$ met. Adenocarcinoma, 1(2\%) met. squamous cell carcinoma,

2(4\%) intramoucosal adenocarcinoma, 4(8\%) mucinous adenocarcinoma,

2(4\%) signet ring adenocarcinoma, 1(2\%) met. signet ring adenocarcinoma,

$1(2 \%)$ met. mucinous adenocarcinoma 
Table (2): Patients characteristics of the after treatment cancer colon group

\begin{tabular}{|c|c|c|}
\hline - & & $\mathbf{N}(\%)$ \\
\hline Sex & $\begin{array}{l}\text { Male } \\
\text { Female }\end{array}$ & $\begin{array}{l}10(62.5) \\
6(37.5)\end{array}$ \\
\hline \multirow[t]{4}{*}{ Prognostic factors } & $\begin{array}{l}\text { Stage } \\
\text { II } \\
\text { III } \\
\text { IV }\end{array}$ & $\begin{array}{ll}11 & (68.75) \\
4 & (25) \\
1 & (6.25) \\
\end{array}$ \\
\hline & $\begin{array}{l}\text { Grade } \\
\text { II } \\
\text { III } \\
\end{array}$ & $\begin{array}{l}15(93.75) \\
1(6.25) \\
\end{array}$ \\
\hline & $\begin{array}{l}\text { Pathology } \\
\text { Adenocarcinoma } \\
\text { Met. adenocarcinoma }\end{array}$ & $\begin{array}{l}16(93.75) \\
1(6.25)\end{array}$ \\
\hline & Tumor site & \\
\hline
\end{tabular}

Table (3): Comparison between all studied tumor markers in the four studied groups

\begin{tabular}{|l|c|c|c|c|c|c|}
\hline & Control & Benign & Malignant & After treat. & $\begin{array}{c}\text { F. } \\
\text { value }\end{array}$ & $\begin{array}{c}\text { p. } \\
\text { value }\end{array}$ \\
\cline { 2 - 6 } & $\begin{array}{c}\text { Mean } \pm \\
\text { SD }\end{array}$ & $\begin{array}{c}\text { Mean } \pm \\
\text { SD }\end{array}$ & $\begin{array}{c}\text { Mean } \pm \\
\text { SD }\end{array}$ & Mean \pm SD & & \\
\hline CEA ng/ml & $5.1 \pm 2.4$ & $23.3 \pm 5.6$ & $108.9 \pm 36.1$ & $12.59 \pm 4.94$ & 104.60 & $<.0001^{*}$ \\
\hline CA19.9 U $/ \mathrm{ml}$ & $24.3 \pm 7.8$ & $44.8 \pm 8.3$ & $255.8 \pm 83.6$ & $36.76 \pm 10.9$ & 103.40 & $<.0001^{*}$ \\
\hline MMP9 ng/ml & $39.2 \pm 8.5$ & $70.3 \pm 6.2$ & $107.4 \pm 8.5$ & $67.53 \pm 11.81$ & 253.28 & $<.0001^{*}$ \\
\hline $\begin{array}{l}\text { Galectin3 } \\
\text { ng/ml }\end{array}$ & $4.18 \pm 1.08$ & $5.69 \pm 0.75$ & $10.2 \pm 1.24$ & $1.93 \pm 0.54$ & 305.94 & $<.0001^{*}$ \\
\hline
\end{tabular}


Table (4): Comparisons between the studied tumor markers and some prognostic factors in the cancer colon group

\begin{tabular}{|c|c|c|c|c|c|c|c|c|c|c|c|c|}
\hline & \multicolumn{3}{|l|}{ Tumor site } & \multicolumn{3}{|c|}{ Lymph node } & \multicolumn{3}{|c|}{ Distance metastasis } & \multicolumn{3}{|l|}{ Sex } \\
\hline & $\begin{array}{l}\text { Ascending } \\
\text { Mean } \pm \text { SD }\end{array}$ & $\begin{array}{l}\text { Descending } \\
\text { Mean } \pm \text { SD }\end{array}$ & $\begin{array}{l}\text { p- } \\
\text { value }\end{array}$ & $\begin{array}{l}\text { +ve } \\
\text { Mean } \\
\pm \mathrm{SD}\end{array}$ & $\begin{array}{l}+\mathbf{e} \\
\text { Mean } \\
\pm \mathrm{SD}\end{array}$ & p-value & $\begin{array}{l}\text { +ve } \\
\text { Mean } \\
\pm \mathrm{SD}\end{array}$ & $\begin{array}{l}\text {-ve } \\
\text { Mean } \\
\pm \mathrm{SD}\end{array}$ & p-value & $\begin{array}{l}\text { Female } \\
\text { Mean } \\
\pm \mathrm{SD}\end{array}$ & $\begin{array}{l}\text { male } \\
\text { Mean } \\
\pm \mathrm{SD}\end{array}$ & $\begin{array}{l}p- \\
\text { value }\end{array}$ \\
\hline CEA & $\begin{array}{l}118.1 \pm \\
40.58\end{array}$ & $\begin{array}{l}104.9 \pm \\
33.6\end{array}$ & 0.1592 & $\begin{array}{l}149.5 \pm \\
22.6\end{array}$ & $\begin{array}{l}149.5 \pm \\
22.6\end{array}$ & $<.0001^{*}$ & $\begin{array}{l}146.05 \pm \\
51.5\end{array}$ & $\begin{array}{l}103.11 \pm \\
29.6\end{array}$ & $0.0026^{*}$ & $\begin{array}{l}107.5 \pm \\
30.8\end{array}$ & $\begin{array}{l}110.8 \pm \\
41.67\end{array}$ & 0.748 \\
\hline CA19.9 & $\begin{array}{l}285.4 \pm \\
102.9 \\
\end{array}$ & $\begin{array}{l}241.9 \pm \\
70.33\end{array}$ & 0.4231 & $\begin{array}{l}286.2 \pm \\
75\end{array}$ & $\begin{array}{l}286.2 \pm \\
75\end{array}$ & 0.2399 & $\begin{array}{l}365.8 \pm \\
99.4\end{array}$ & $\begin{array}{l}237.95 \pm \\
66.3\end{array}$ & $<.0001 *$ & $\begin{array}{l}238.3 \pm \\
67.7\end{array}$ & $\begin{array}{l}274.8 \pm \\
95.8\end{array}$ & 0.124 \\
\hline Galectin3 & $\begin{array}{l}10.4 \pm \\
1.56\end{array}$ & $\begin{array}{l}9.9 \pm \\
1.05\end{array}$ & 0.1511 & $\begin{array}{l}9.86 \pm \\
2\end{array}$ & $\begin{array}{l}9.86 \pm \\
2\end{array}$ & 0.9672 & $\begin{array}{l}11.3^{ \pm} \\
1.04\end{array}$ & $\begin{array}{l}9.93 \pm \\
1.16\end{array}$ & $0.0044 *$ & $\begin{array}{l}10.16 \pm \\
1.24\end{array}$ & $\begin{array}{l}10 \pm \\
1.27\end{array}$ & 0.837 \\
\hline МMP 9 & $\begin{array}{l}107.4 \pm \\
10.8 \\
\end{array}$ & $\begin{array}{l}107.4 \pm \\
7.4\end{array}$ & 0.5443 & $\begin{array}{l}110.57 \pm \\
14\end{array}$ & $\begin{array}{l}110.57 \pm \\
14\end{array}$ & 0.3057 & $\begin{array}{l}110.1 \pm \\
9.38 .59 \\
\end{array}$ & $\begin{array}{l}107.35 \pm \\
8.02\end{array}$ & 0.8389 & $\begin{array}{l}107.48 \pm \\
8.12\end{array}$ & $\begin{array}{l}107.42 \pm \\
9.1\end{array}$ & 0.97 \\
\hline
\end{tabular}




\section{Continued Table (4)}

\begin{tabular}{|c|c|c|c|c|c|c|c|c|c|c|}
\hline \multirow{2}{*}{ 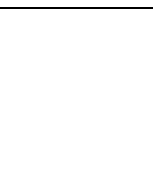 } & \multicolumn{4}{|l|}{ Stage } & \multicolumn{3}{|l|}{ Grade } & \multicolumn{3}{|l|}{ Pathology } \\
\hline & $\begin{array}{l}\text { Stage II } \\
\text { Mean } \pm \text { SD }\end{array}$ & $\begin{array}{l}\text { Stage III } \\
\text { Mean } \pm \text { SD }\end{array}$ & $\begin{array}{l}\text { Stage IV } \\
\text { Mean } \\
\pm \mathrm{SD} \\
\end{array}$ & $\begin{array}{l}\text { P- } \\
\text { value }\end{array}$ & $\begin{array}{l}\text { Grade II } \\
\text { Mean } \pm \text { SD }\end{array}$ & $\begin{array}{l}\text { Grade III } \\
\text { Mean } \pm \text { SD }\end{array}$ & $\begin{array}{l}\text { P- } \\
\text { value }\end{array}$ & $\begin{array}{l}\text { Adenoca- } \\
\text { rcinoma } \\
\text { Mean } \pm \text { SD }\end{array}$ & $\begin{array}{l}\text { Others } \\
\text { Mean } \pm \text { SD }\end{array}$ & p-value \\
\hline CEA & $\begin{array}{l}146.33 \pm \\
20.9\end{array}$ & $\begin{array}{l}90 \pm \\
16.35 \\
\end{array}$ & $\begin{array}{l}146 \pm \\
51.5 \\
\end{array}$ & $\begin{array}{l}0.0001 \\
*\end{array}$ & $\begin{array}{l}109.12 \pm \\
35.29\end{array}$ & $\begin{array}{l}109.1 \pm \\
57.3\end{array}$ & 0.6000 & $\begin{array}{l}106.2 \pm \\
30.7\end{array}$ & $\begin{array}{l}89.5 \pm \\
20.1 \\
\end{array}$ & 0.1980 \\
\hline CA19.9 & $\begin{array}{l}269.5 \pm \\
53\end{array}$ & $\begin{array}{l}228.3 \pm \\
67.67\end{array}$ & $\begin{array}{l}365.8 \pm \\
99.4\end{array}$ & $\begin{array}{l}0.0041 \\
*\end{array}$ & $\begin{array}{l}255 \pm \\
203.1\end{array}$ & $\begin{array}{l}265 \pm \\
110.69\end{array}$ & 0.5045 & $\begin{array}{l}230.6 \pm \\
61.7\end{array}$ & $\begin{array}{l}270.1 \pm \\
80.3\end{array}$ & $0.0043^{*}$ \\
\hline $\begin{array}{l}\text { Galectin } \\
3\end{array}$ & $\begin{array}{l}9.6 \pm \\
1.93 \\
\end{array}$ & $\begin{array}{l}10 \pm \\
0.8 \\
\end{array}$ & $\begin{array}{l}11.33 \pm \\
1.04\end{array}$ & 0.1918 & $\begin{array}{l}10.14 \pm \\
1.26\end{array}$ & $\begin{array}{l}9.9 \pm \\
0.85 \\
\end{array}$ & 0.4588 & $\begin{array}{l}9.92 \pm \\
1.23 \\
\end{array}$ & $\begin{array}{l}9.98 \pm \\
0.88 \\
\end{array}$ & 0.1330 \\
\hline MMP 9 & $\begin{array}{l}108.57 \pm \\
12.9\end{array}$ & $\begin{array}{l}106.98 \pm \\
6.02\end{array}$ & $108 \pm 11.9$ & 0.7508 & $107.3 \pm 8.59$ & $\begin{array}{l}109.3 \pm \\
8.8\end{array}$ & 0.5515 & $\begin{array}{l}106.7 \pm \\
7.68\end{array}$ & $\begin{array}{l}110.15 \pm \\
9.38\end{array}$ & 0.9179 \\
\hline
\end{tabular}

(*) significant $\leq 0.05$

Others pathology $=2(4 \%)$ metadenocarcinoma, $1(2 \%)$ metsquamous cell carcinoma, 2(4\%) intramoucosal adenocarcinoma, 4( $8 \%)$ mucinous adenocarcinoma, 2(4\%) signet ring adenocarcinoma, 1(2\%) metsignet ring adenocarcinoma, 1(2\%) metmucinous adenocarcinoma 
Table (5): Diagnostic performance of CEA, Galectin 3, CA19.9, MMP9

\begin{tabular}{|l|l|l|l|l|}
\hline Cutoff value & $\begin{array}{l}\text { CEA } \\
(21 \mathrm{ng} / \mathrm{ml})\end{array}$ & $\begin{array}{l}\text { CA19.9 } \\
(58 \mathrm{U} / \mathrm{ml})\end{array}$ & $\begin{array}{l}\text { MMP9 } \\
(90.9 \mathrm{ng} / \mathrm{ml})\end{array}$ & $\begin{array}{l}\text { Galectin 3 } \\
(4.8 \mathrm{ng} / \mathrm{ml})\end{array}$ \\
\hline Sen \% & 92.3 & 81.5 & 75.4 & 96.9 \\
Sen (95\% CI) & $(82.7-97)$ & $(70.2-89.2)$ & $(63.6-84.3)$ & $(88.7-99.7)$ \\
\hline Sp \% & 100 & 100 & 100 & 90.3 \\
sp (95\% CI) & $(86.6-100)$ & $(86.6-100)$ & $(86.6-100)$ & $(74.1-97.3)$ \\
\hline PPV \% & 100 & 100 & 100 & 95.5 \\
\hline NPV \% & 86.1 & 72.1 & 66 & 93.3 \\
\hline $\begin{array}{l}\text { Diagnostic } \\
\text { Accuracy \% }\end{array}$ & 94.8 & 87.5 & 83.3 & 94.8 \\
\hline
\end{tabular}

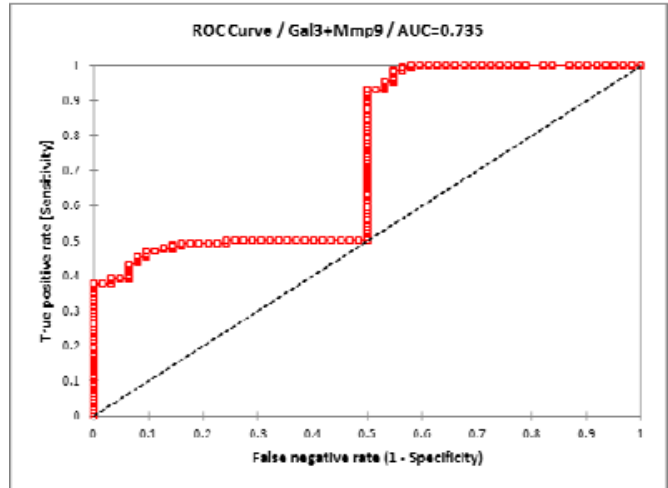

Figure (1) ROC curve of Galectin3 / MMP9 cutoff value $(4.8 \mathrm{ng} / \mathrm{ml}-90.9 \mathrm{ng} / \mathrm{ml})$

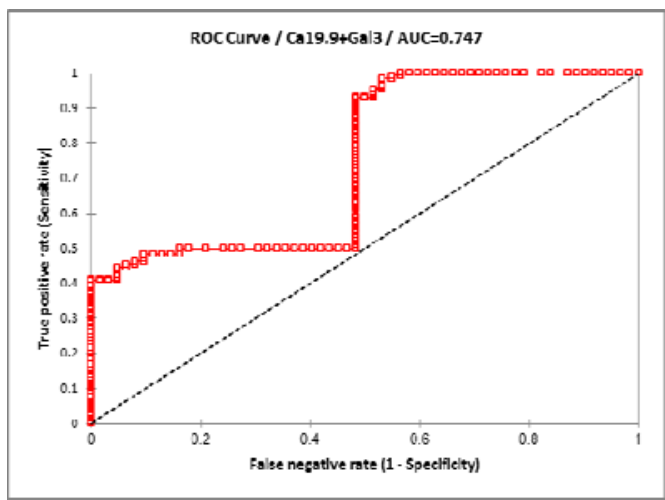

Figure (3) ROC curve of Galectin3 / CA19.9 cutoff value $(90.9 \mathrm{ng} / \mathrm{ml}-58 \mathrm{U} / \mathrm{ml})$

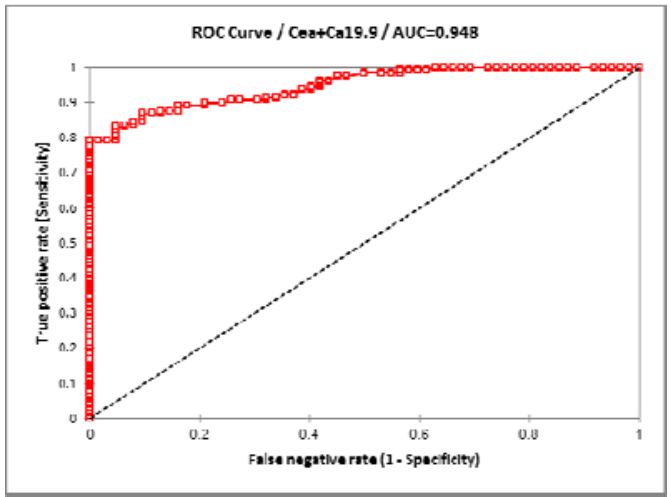

Figure (1) ROC curve of CEA / CA19.9 cutoff value $(21 \mathrm{ng} / \mathrm{ml}-58 \mathrm{U} / \mathrm{ml})$

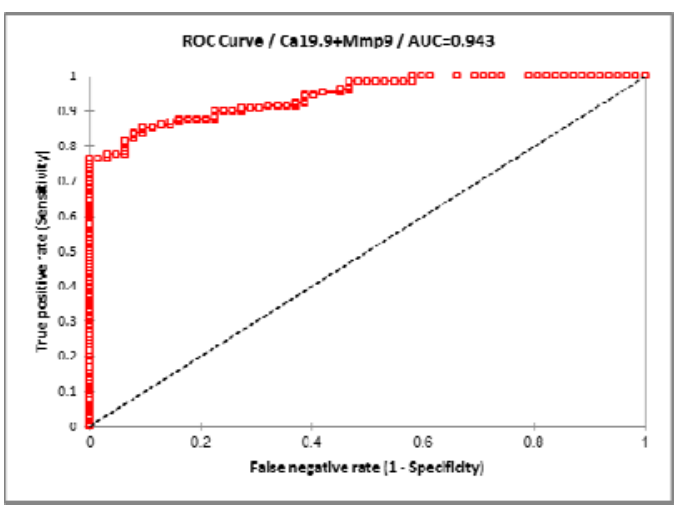

Figure (4) ROC curve of MMP9 / CA19.9 cutoff value $(4.8 \mathrm{ng} / \mathrm{ml}-58 \mathrm{U} / \mathrm{ml})$ 


\section{DISCUSSION}

Colorectal cancer (CRC) is the third most common malignancy in the world. In addition, there are approximately 800,000 new cases of CRC and 450,000 deaths associated with CRC each year. Studies have shown that shifting the detection of the disease to an earlier stage via mass screening, and intervening at that stage could reduce the risk of death from CRC. These findings strongly demonstrate the clinical need for biomarkers for early detection of CRC $^{(15)}$. In Egypt, the relative frequency of cancer colon at the National cancer Institute, Cairo University from 2002 to 2007 was (3$5 \%)^{(2)}$.

The endogenous, $\beta$-galactosidebinding protein galectin-3 is a member of a family of carbohydratebinding proteins that have been implicated in cell growth, differentiation, adhesion and malignant transformation ${ }^{(3)}$. It also, plays a role in the metastasis of several carcinomas ${ }^{(4)}$. Another important role of galectin-3 in cancer may be its ability to regulate apoptosis, acting as an anti-apoptotic factor ${ }^{(16)}$. Recent studies have demonstrated that galectin-3 is a novel CD95-binding partner. CD95 is a member of the death receptor family ${ }^{(17)}$ with which galectin-3 interacts and determines which of the CD95 apoptotic signaling pathways the cell will select ${ }^{(3)}$.

The expression of galectin- 3 was found to be uniformly elevated with neoplastic progression in certain malignancies including thyroid ${ }^{(18)}$, pulmonary (19), gastric (20), colon cancer $^{(21)}$, and anaplastic large-cell lymphoma ${ }^{(22)}$. Meanwhile, several studies have shown that decreased expression of galectin-3 is associated with malignancies including breast ${ }^{(23)}$, cervical $^{(24)}$ melanoma ${ }^{(25)}$ and colorectal cancer $^{(26)}$. This suggests that inconsistent and varying amounts of galectin-3 expression in tumors of the same origin reflect the heterogenicity of tumor cells; therefore, the existence of a correlation between galectin- 3 and the malignancy is unlikely.

Matrix metalloproteinase 9 or gelatinase $\mathrm{B}$ is a member of matrix metalloproteinases family which is structurally related to zinc-dependent endopeptidases proteolytic enzymes that are collectively capable of degrading essentially all components of extracellular matrix including the basement membrane and type IV collagen. They are associated with tissue remodeling in normal and pathological processes characterized by excessive degradation of $\mathrm{ECM}^{(6)}$, as rheumatoid arthritis, osteoarthritis, periodontitis, autoimmune blistering disorders of the skin, they also play a role in the development, invasion and metastasis $^{(7)}$ of malignant tumors as colorectal $^{(8)}$, gastric ${ }^{(9)}$, lung ${ }^{(10)}$, and breast cancer ${ }^{(11)}$.

The aim of the present work was to evaluate the diagnostic role of galectin3 and matrix metalloproteinase 9 in colon cancer patients, and to compare them with the benign colon patients group, after treatment patients group, and normal healthy control group. Serum concentrations of both markers were 
also compared with CEA, CA19,9 and some prognostic factors of cancer colon.

The aim of the present work was to evaluate the diagnostic role of galectin3 and matrix metalloproteinase9 in colon cancer patients, and to compare them with the benign colon patients group, after treatment patients group, and normal healthy control group. Serum concentration of both markers were also compared with CEA, CA19,9 and some prognostic factors of cancer colon.

In the present study, comparing the four studied tumor markers (CEA, CA19.9, galectin3 and MMP9) between the different groups (colon cancer before treatment, benign colon disease, colon cancer after treatment and control group), revealed statistically significant difference for all markers ( $p$-value $<0.0001$ for each).

Pair wise comparison of the studied tumor markers between the different groups revealed statistically significant differences between each pair.

In the current study, galectin 3 , showed the highest results in the malignant group, followed by the benign then the control and lastly comes the after treatment group $(10.2 \pm 1.24,5.69 \pm 0.75,36.4 .18 \pm 1.08$ and $1.93 \pm 0.54 \mathrm{ng} / \mathrm{ml}$ respectively)

Consistently, up to 5-fold increase of galectin-3 concentration was reported in sera of patients with colorectal cancer compared to the control group in a study by Iurisci et

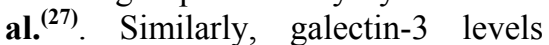
were higher in sera of non metastatic colorectal cancer patients than in controls $(p<0.0001)$, particularly in more differentiated tumors $(\mathrm{p}<0.04)$ in a study by Iacovazzi et al. ${ }^{(5)}$.

Arfaoui-Toumi et al. ${ }^{(28)}$ as well, investigated the involvement of galectin-3 in colorectal cancer development using a comparative immunohistochemical analysis of galectin-3 expression in terms of intensity and distribution in normal mucosa, in primary tumor and in metastasis from 200 patients with colorectal cancer. They found a strong and diffuse positive staining of galectin-3 in both adjacent and distanced normal mucosa, in well differentiated adenocarcinoma and in metastasis.

In the present study, MMP9, CEA , and CA 19.9 showed highest results in the malignant group, followed by the benign then the after treatment and lastly comes the control group. While galectin 3 showed higher results in the control group compared to the after treatment group, MMP9, CEA and CA 19.9 showed higher results in the after treatment group compared to the control group.

Consistently, the preoperative serum levels of MMP-9, TIMP-1, CEA, and CA 19-9 were significantly higher in the CRC group than in the healthy subjects in a study by Barbara et al. ${ }^{(29)}$. Also, Hurst et al ${ }^{(\mathbf{( 8 )}}$ detected significant differences between MMP9 concentrations in non-neoplastic and neoplastic conditions $(\mathrm{P}<0.0001)$ in their study done on 63 patients with cancer colon, 27 with significant adenomas and 46 normal controls. Similarly, both realtime PCR and immunohistochemistry evaluation have demonstrated MMP-9 over-expression in colorectal cancer 
tissues compared with normal mucosa $(p<0.001)$ in a study by Zhang et al. ${ }^{(30)}$.

Also, Guzinska-Ustymowicz ${ }^{(31)}$ studied the immunohistochemical expression of MMP9 in 55 specimens of colorectal adenocarcinoma and showed positive immunostaining for MMP9 in the primary tumor which was observed in 30/55 (54.6\%) cases $(\mathrm{p}<0.01)$.

Another study done in Upper Egypt, by Ola et al., (32) and confirmed by our results, she studied the MMP9 expression by immunohistochemical analysis in human colorectal cancer and the correlation of that expression with the prognostic factors. The study showed that MMP-9 was expressed in $72 \%$ (strong expression in 35\% of cases). Increased levels of MMP-9 protein expression in colorectal carcinoma tissues as compared to normal tissues suggest their association with colorectal tumor invasion and metastasis.

In the present study, on comparing CEA with the different prognostic factors, the comparison was statistically significant for stage, lymph node and distant metastasis (pvalue $0.0001,0.0001$ and 0.0026 respectively), CA19.9 was statistically significant for distant metastasis, stage and pathology (p-value <.0001, 0.0041 and 0.0043 respectively). As regards MMP9, there was no significant results with the stage, grade or lymph node or distant metastasis ( $p$-value $0.75,0.55,0.30$ and 0.8 respectively).

In contrast to our results, many authors detected significant correlations when comparing MMP-9 to different prognostic factors, this discrepancy might be attributed to the difference in the ethnic group studied, or different techniques or sample size used,

MMP-9 expression was significantly higher in patients with low-grade differentiation and distant metastasis $(p=0.003$ and $p=0.005$, respectively), and patients with MMP9-positive expression had a poorer prognosis $(p=0.008)$ in a study by Zhang et al., ${ }^{(29)}$.

Vacirca, Zucker ${ }^{(33)}$ showed that the over-expression of MMP-1, -2, -3. $-7,-9,-13$ have been demonstrated in human colorectal cancers. The degree of over-expression of some MMPs has been noted to correlate with stage of disease and/or prognosis.

Also, Chu et al. (34) found that MMP-9 expression tended to increase from $\mathrm{T} 1$ to $\mathrm{T} 4 \quad(\mathrm{P}<0.001)$. Further analysis of the correlation between MMP-9 expression and node status revealed that node positive colorectal cancer samples had more MMP-9positive expression than did nodenegative ones $(\mathrm{P}<0.001)$. Regarding distant metastasis, M1 colorectal cancer samples had more positive MMP-9 staining than did M0 ones, whereas MMP-9 expression was not correlated with patient gender, age, tumor location or differentiation status.

Also, the levels of MMP-9, TIMP-1, CEA and CA 19.9 correlated with the Duke's stage and were the highest in the sera of CRC patients with stage D in a study by Barbra et al. $^{\text {(29) }}$. Similarity, a statistically significant association was found between the expression of MMP9 and 
lymph node metastasis in a study by Guzinska-Ustymowicz ${ }^{(31)}$.

Ggalectin-3 has pleiotropic biological functions and has been implicated in cell growth, differentiation, adhesion, RNA processing, apoptosis, and malignant transformation ${ }^{(35)}$. Bresalier et al., ${ }^{(36)}$ reported that galectin-3 expression was correlated with colon cancer metastasis. Galectin-3 provides tumor cells with anti-apoptotic and anti anoikis activities, which are thought to be critical for anchorage-independent cell survival in the circulation that takes place during dissemination ${ }^{(37)}$. Changes in circulating galectin-3 levels in cancer patients may contribute significantly to the metastatic spread of disseminating cancer cells by enhancing their ability to adhere to blood vessel endothelium and by helping their avoidance of immune surveillance. Thus, targeting the galectin-3 actions in the circulation may hold significant promise for future development of novel therapeutic agents to prevent metastasis and reduce cancerassociated fatality ${ }^{(38)}$.

In the current study, galectin3 was statistically significant for distant metastasis (p-value 0.0044); while there was no significant results when compared to other prognostic factors. Iurisci et al, ${ }^{(27)}$ postulated that patients with metastatic disease have higher concentrations of circulating galectin-3 than those with localized tumors. The source of increased serum galectin-3 in cancer patients remains unknown but has been speculated to be generated by the tumor cells as well as the peri-tumoral inflammatory and stromal cells.
Similarly, there was no significant correlation between galectin-3 expression and some prognostic factors, such as age, gender, histological type, lymph node metastasis, and tumor stage, but in contrast to our results, Kaori et al., ${ }^{(39)}$ found no relation between galectin3 and liver metastasis.

Endo et al ${ }^{(21)}$ demonstrated that galectin 3 was significantly related to pathological type, lymph node metastasis, and distant metastasis. Galectin-3 expression was found to be an independent prognostic factor ranking with lymph node metastasis and prognosis in his study on 121 patients with colorectal cancer.

In contrast, John et al. ${ }^{(37)}$ showed that galectin-3 is efficacious in reducing metastases and tumor volumes and weights in primary tumors in a nude mouse model of human breast cancer. However, inconsistent and varying amounts of galectin-3 expression in tumors of the same origin reflect the heterogeneity of tumor cells; therefore, the existence of a correlation between galectin-3 and malignancy is unlikely.

In this study, on studying the diagnostic performance of all the studied at the chosen cutoffs, CEA (21 ng/ml), CA19.9 (58 U/ml), MMP9 $(90.9 \mathrm{ng} / \mathrm{ml})$ and galectin 3 (4.8 $\mathrm{ng} / \mathrm{ml})$, galectin 3 showed the highest sensitivity, followed by CEA, and then CA19.9 and lastly MMP9 (96.9\%, 92.3\%, 81.5\% and $75.4 \%$ respectively).

As regards specificity \% CEA, CA19.9 and MMP9 showed 100\% specificity each, while galectin 3 shows relatively lower specificity \% (90.3\%). Galectin 3 and CEA showed 
comparable high diagnostic accuracy (94.8\%) followed by CA19.9 (87.5\%) then MMP9 (83.3\%).

CEA may boast a degree of specificity for malignancy; it is also elevated in many diverse states including old age, obesity, smoking, inflammatory lung disease, liver disease, and other diseases of the digestive tract ${ }^{(40)}$. Elevations in CEA levels are also reported in noncolorectal malignancies, including lung $(74 \%)^{(41)}$, breast $(57 \%)$, esophageal, gastric, and pancreatic carcinomas. It is also more likely to be elevated in disseminated disease than in locally confined (and hence surgically curable) lesions ${ }^{(42)}$.

Barbra et al. ${ }^{(29)}$ calculated the sensitivities of MMP-9 as 55\%, CEA as $39 \%$, and CA $19-9$ as $11 \%$. The diagnostic sensitivity of biomarkers tested increased with their combined use.

In this study, galectin3 had the highest sensitivity and slightly low specificity, while MMP9, CEA and CA 19.9 showed the lowest sensitivity and $100 \%$ specificity, so using the markers in combination might provide high sensitivity and specificity.

On comparing sensitivity and specificity and diagnostic accuracy for the studied tumor markers in double combinations, the best sensitivity $(98.5 \%)$ was obtained when combining galectin 3 \& CA19.9 at cut offs $\quad\left(\begin{array}{lllll}4.8 & \mathrm{ng} / \mathrm{ml} & - & 58 & \mathrm{U} / \mathrm{ml}\end{array}\right)$ respectively and galectin $3 \&$ MMP9 at cutoffs $(4.8 \mathrm{ng} / \mathrm{ml}-90.9 \mathrm{ng} / \mathrm{m})$ respectively.

As regards specificity, the double combination between CEA \& CA19.9 at cut offs $(21 \mathrm{ng} / \mathrm{ml}-58 \mathrm{U} / \mathrm{ml})$ respectively and MMP9 \& CA19.9 at cut offs $(90.9 \mathrm{ng} / \mathrm{ml}-58 \mathrm{U} / \mathrm{ml})$ respectively showed the highest specificity of $100 \%$ each, followed by CEA \& MMP9 at cut offs $(21 \mathrm{ng} / \mathrm{ml}-$ $90.9 \mathrm{ng} / \mathrm{ml}$ ) respectively with specificity of $91.9 \%$.

On studying the correlation between all the studied tumor markers, there were significant positive correlations between CEA \& CA19.9, CEA \& galectin 3, CEA \& MMP9, CA19.9 \& Galectin 3, CA19.9 \& MMP9 and MMP9 \& Galectin $3(\mathrm{p}=0.0001)$ each.

The collagen-like domain of galectin-3 is susceptible to rapid and efficient cleavage by MMPs, in particular MMP-2, MMP-9, and membrane type 1-MMP resulting in the generation of a $22 \mathrm{kDa}$ cleaved product $^{(14)}$. This might explain the significant positive correlation found between galectin3 and MMP-9. Also, the significant positive correlation between galectin3 and CEA in the present study might be explained by the fact that galectin-3 may express its malignant potential through regulation of apoptotic signal transduction by interaction with its ligands. The ligands identified in colon cancer include mucin, Mac-2-binding protein, CEA, lamp 1 and lamp 2 glycoproteins, and haptoglobin related protein $^{(43)}$. So, increase in galectin3 may be associated with increase in CEA which acts as its ligand.

Conclusion: higher concentrations of galectin 3 and MMP9 in the cancer colon group compared to the benign and normal control groups which make them potential diagnostic markers for CRC. Also, being higher in the malignant group compared to the after treatment 
group makes them suitable for follow up of CRC patients during the course of treatment. The high sensitivity of galectin3 and high specificity of MMP9, CEA and CA19.9 encourage the use of double combinations between galectin3 and any of the former 3 markers in order to improve the diagnostic accuracy. Further studying of larger number of cases and long term follow up for the patients is recommended to support these results and to detect whether these markers could predict patients' survival or not.

\section{REFERENCE}

1. Greenlee RT, Murray T, Bolden S, Wingo PA. (2000): Cancer statistics, 2000. CA Cancer J. Clin., 50: 7-33.

2. National Cancer Institute Registry, 2002- 2007.

3. Fukumori T, Takenaka Y, Oka N, Yoshii T, Hogan V, Inohara H, Kanayama HO, Kim HR, Raz A. (2004): Endogenous galectin-3 determines the routing of CD95 apoptotic signaling pathways. Cancer Res., 64(10):3376-3379.

4. Takenaka, Y.; Fukumori, T.; Raz, A.(2004): Galectin-3 and metastasis. Glycoconjugate J., 19 (7-9): 543-549.

5. Iacovazzi P. A.; Notarnicola M.; Caruso M. G.; Guerra V.; Frisullo S.; Altomare D. F.; Correale M.(2010): Serum levels of galectin-3 and its ligand $90 \mathrm{k} / \mathrm{mac}-2 \mathrm{bp}$ in colorectal cancer patients. Immunopharmacology and Immunotoxicology 32 (1): 160-164.
6. Collins HM, Morris TM, Watson SA (2001): Spectrum of matrix metalloproteinase expression in primary and metastatic colon cancer: relationship to the tissue inhibitors of metalloproteinases and membrane type-1-matrix metalloproteinase. Br. J. Cancer 84(12): $1664-70$.

7. Westermarck J, Kahari VM. (1999): Regulation of matrix metalloproteinase expression in tumor invasion. FASEB J., 13(8):781-792.

8. Hurst NG, Stocken DD, Wilson S, Keh C, Wakelam MJ, Ismail T. (2007: Elevated serum matrix metalloproteinase 9 (MMP-9) concentration predicts the presence of colorectal neoplasia in symptomatic patients. British Journal of Cancer 97(7): 971 977.

9. Torii A, Kodera Y, Uesaka K, Hirai T, Yasui K, Morimoto T, Yamamura $Y$, Kato $T$, Hayakawa T, Fujimoto N, and Kito T (1997): Plasma concentration of matrix metalloproteinase 9 in gastric cancer. Br. J. Surg., 84(1):133136.

10. Ylisirnio S, Hoyhtya M, Turpeenniemi-Hujanen $T$. (2000): Serum matrix metalloproteinases $-2, \quad-9$ and tissue inhibitors of metalloproteinases $-1,-2$ in lung cancer--TIMP-1 as a prognostic marker. Anticancer Res., 20(2B): 1311-1316.

11. Wu ZS, Wu Q, Yang JH, Wang HQ, Ding XD, Yang F, Xu XC. (2008): Prognostic significance of 
MMP-9 and TIMP-1 serum and tissue expression in breast cancer," Int. J. Cancer 122(9):2050-2056.

12. Chan $\mathrm{CC}$, Menges $\mathrm{M}$, Orzechowski HD, Orendain N, Pistorius G, Feifel G, Zeitz M, Stallmach A. (2001): Increased matrix metalloproteinase 2 concentrations and transcript expression in advanced colorectal carcinomas. Int. J. Colorectal Dis., 16(3):133- 140.

13. Gong HC, Honjo Y, NangiaMakker P, Hogan V, Mazurak N, Bresalier RS, Raz A. (1999): The NH2 terminus of galectin-3 governs cellular compartmentalization and functions in cancer cells. Cancer Res., 59(24): 6239-45.

14. Ochieng J, Fridman R, NangiaMakker P, Kleiner DE, Liotta LA, Stetler-Stevenson WG, Raz A. (1994): Galectin-3 is a novel substrate for human matrix metalloproteinases-2 and -9 . Biochemistry 33(47): 1410914114.

15. Sung JJ, Lau JY, Goh KL, Leung WK; Asia Pacific Working Group on Colorectal Cancer. (2005): Increasing incidence of colorectal cancer in Asia: implications for screening. Lancet Oncol., 6(11): 871-6.

16. Matarrese P., Tinari N., Semeraro M.L., Natoli C., Iacobelli S., Malorni W. (2000): Galectin-3 overexpression protects from cell damage and death by influencing mitochondrial homeostasis, FEBS Lett. 473 (3): 311-315.
17. Nagata S. (1997): Apoptosis by death factor. Cell 88(3): 355-365.

18. Saggiorato E, Aversa $S$, Deandreis D, Arecco F, Mussa A, Puligheddu B, Cappia S, Conticello S, Papotti M, Orlandi F. (2004): Galectin-3: presurgical marker of thyroid follicular epithelial cell-derived carcinomas. J. Endocrinol. Invest., 27(4): 311-317.

19. Buttery R, Monaghan H, Salter DM and Sethi T. (2004): Galectin-3: differential expression between small cell and non-small cell lung cancer. Histopathology 44(4): 339-344.

20. Lotan $R$, Ito $H$, Yasui $W$, Yokozaki H, Lotan D and Tahara E. (1994): Expression of a $31-\mathrm{kDa}$ lactoside-binding lectin in normal human gastric mucosa and in primary and metastatic gastric carcinomas. Int. J. Cancer 56(4): 474-480.

21. Endo, K.; Kohnoe, S.; Tsujita, E.; Watanabe, A.; Nakashima, H.; Baba, H.; Maehara, Y. (2005): Galectin- 3 expression is a potent prognostic marker in colorectal cancer. Anticancer Res., 25(4): 3117-3121.

22. Konstantinov KN, Robbins BA and Liu FT (1996): Galectin-3, a betagalactoside- binding animal lectin, is a marker of anaplastic large-cell lymphoma. Am. J. Pathol., 148(1): 25-30.

23. Castronovo V, Van Den Brûle FA, Jackers P, Clausse N, Liu FT, Gillet C, Sobel ME. (1996): Decreased expression of galectin3 is associated with progression of human breast cancer. J. Pathol., 179(1): 43-48. 
24. Lee MR, Hong CW, Yoon SN, Lim SB, Park KJ, Lee MJ, Kim WH, Park JG (2006): Isolated tumor cells in lymph nodes are not a prognostic marker for patients with stage I and stage II colorectal cancer. J. Surg. Oncol., 93(1):13- 18.

25. Van Den Brule FA, Buicu $C$, Sobel ME, Liu FT and Castronovo V. (1995): Galectin3, a laminin binding protein, fails to modulate adhesion of human melanoma cells to laminin. Neoplasma 42(5): 215-219.

26. Lotz MM, Andrews $\mathrm{CW} \mathrm{Jr}$, Korzelius CA, Lee EC, Steele GD Jr, Clarke A and Mercurio AM. (1993): Decreased expression of Mac-2 (carbohydrate binding protein 35) and loss of its nuclear localization are associated with the neoplastic progression of colon carcinoma. Proc. Natl. Acad. Sci. USA 90(8): 3466-3470.

27. Iurisci I, Tinari N, Natoli C, Angelucci D, Cianchetti E, Iacobelli S. (2000): Concentrations of galectin-3 in the sera of normal controls and cancer patients. Clin Cancer Res., 6(4):1389-93.

28. Arfaoui-Toumi A, Kria-Ben Mahmoud L, Ben Hmida $M$, Khalfallah MT, Regaya-Mzabi S, Bouraoui S. (2010): Implication of the Galectin-3 in colorectal cancer development (about 325 Tunisian patients). Bull. Cancer 97(2):E1-8.

29. Mroczko B, Groblewska $M$, Okulczyk B, Kedra B, Szmitkowski M. (2010): the diagnostic value of matrix metalloproteinase 9 (MMP-9) and tissue inhibitor of matrix metalloproteinases 1 (TIMP-1) determination in the sera of colorectal adenoma and cancer patients. Int. J. Colorectal Dis., 25(10):1177-1184.

30. Zhang Y, Guan XY, Dong B, Zhao M, Wu JH, Tian XY, Hao CY. (2012): Expression of MMP-9 and WAVE3 in colorectal cancer and its relationship to clinicopathological features. J. Cancer Res. Clin. Oncol., 138(12):2035-44.

31. Guzinska-Ustymowicz K, (2006): MMP9 and casthepsin B expression in tumor buding as an indicator of a more aggressive phenotype of colorectal cancer (CRC). Anticancer Research 26(2B): 1589 -1594 (2006).

32. Ola M. Omran, MD, PhD, Mostafa Thabet, MD. (2003): Gelatinases A and B Expression in Human Colorectal Cancer in Upper Egypt: A clinicopathological study April 2012, Vol. 36, No. 2, Pages 108116

(doi:10.3109/01913123.2011.641 671) Departments of Pathology, Faculty of Medicine, Department of Surgery, Assiut University, Egypt.

33. Vacirca J, Zucker S, (2004): Role of matrix metalloproteinases (MMPs) in colorectal cancer.

Cancer metastasis Rev., 23(12):101-17.

34. Chu D, Zhao Z, Zhou Y, Li Y, Li J, Zheng J, Zhao Q, Wang W. (2012): Matrix metalloproteinase-9 is associated with relapse and prognosis of 
pateints with colorectal cancer. Ann. Surg. Oncol., 19(1) : 318325.

35. Akahani S, Inohara H, NangiaMakker $P$ and Raz A (1997): Galectin- 3 in tumor metastasis. Trends Glycosci. Glycotech., 9: $69-75$.

36. Bresalier RS, Mazurek N, Sternberg LR, Byrd JC, Yunker CK, Nangia-Makker P, Raz A. (1998): Metastasis of human colon cancer is altered by modifying expression of the betagalactoside-binding protein galectin 3. Gastroenterology 115(2): 287-296.

37. John CM, Leffler H, KahlKnutsson B, Svensson I, Jarvis GA. (2003): Truncated galectin-3 inhibits tumor growth and metastasis in orthotopic nude mouse model of human breast cancer. Clin. Cancer Res., 9(6):2374-2383.

38. Yu L.G. (2010): Circulating galectin-3 in the bloodstream: An emerging promoter of cancer metastasis, World J. Gastrointest. Oncol., 2 (4) 177-180.

39. Tsuboi K, Shimura T, Masuda N, Ide M, Tsutsumi S, Yamaguchi S, Asao T, Kuwano H.,(2007): Galectin-3 Expression in Colorectal Cancer: Relation to
Invasion and Metastasis. Anticancer Research 27(4B): 2289-2296.

40. Ruibal-Morell A (1992): CEA serum levels in non-neoplastic disease. Int. J. Biol. Markers 7(3): 160-166.

41. Dent PB, McCulloch PB, Wesley-James $\mathbf{O}$, MacLaren R, Muirhead W, Dunnett CW (1978): Measurement of carcinoembryonic antigen in patients with bronchogenic carcinoma. Cancer 42(3 Suppl.,): 1484-1491.

42. Beatty JD, Romero C, Brown PW, Lawrence Jr W, Terz JJ (1979): Clinical value of carcinoembryonic antigen: diagnosis, prognosis, and follow up of patients with cancer. Arch. Surg., 114(5): 563- 567.

43. Bresalier RS, Byrd JC, Tessler D, Lebel J, Koomen J, Hawke D, Half E, Liu KF, Mazurek N; Great Lakes-New England Clinical and Epidemiology Center of the Early Detection Research Network. (2004): A circulating ligand for galectin-3 is a haptoglobin-related glycoprotein elevated in individuals with colon cancer. Gatroenterology 127(3): 741748. 
دراسة جلاكتين و ميتالوبرتيناز 9 كعلامات النذير في مرضي سرطان القولون

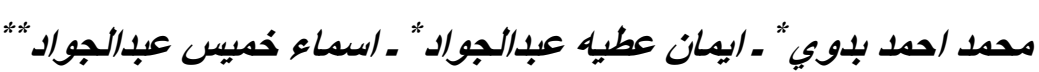

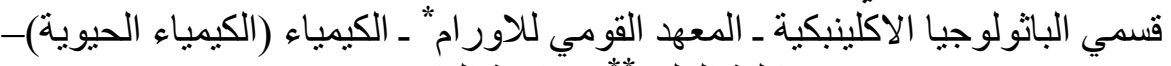

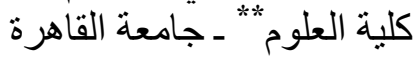

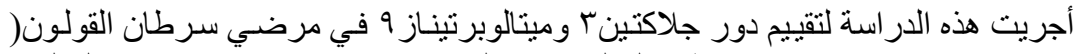

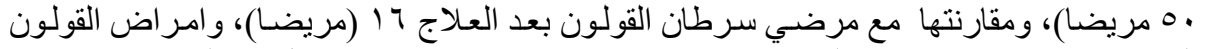

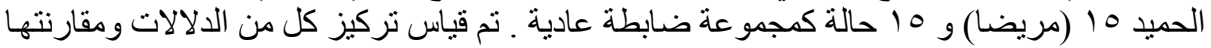
مع بعض دلالات سرطان القولون CEA و 19.9 م 19.9

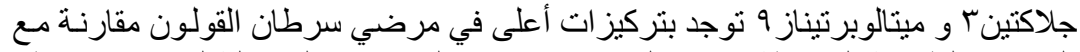

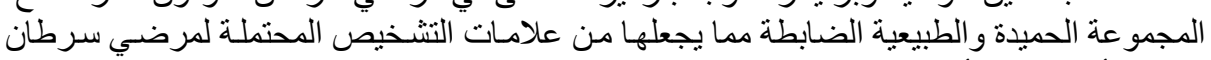

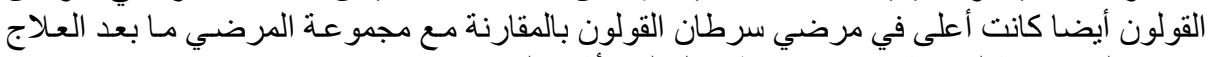

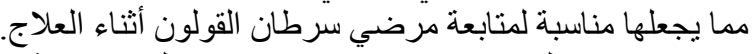

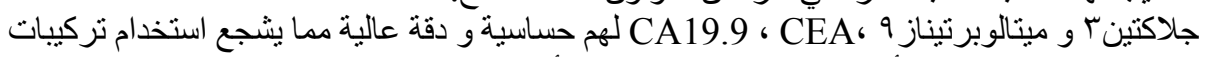
مزدوجة بين جلاكتين و وأي من الدلالات الاخري من أجل تحسين دقة التشخيص. 